\title{
Zinc and Lead Biosorption by Delftia tsuruhatensis: A Bacterial Strain Resistant to Metals Isolated from Mine Tailings
}

\author{
Dorian A. Bautista-Hernández ${ }^{1}$, Landy I. Ramírez-Burgos², Enrique Duran-Páramo³ \\ Luis Fernández-Linares ${ }^{3}$ \\ ${ }^{1}$ Rearch Centre for Environmental Quality, Instituto Tecnológico de Estudios Superiores de \\ Monterrey Campus Estado de México, Atizapán de Zaragoza, México \\ ${ }^{2}$ Faculty of Chemistry, Programa de Ingeniería Química Ambiental y Química Ambiental (PIQAyQA), \\ Universidad Nacional Autónoma de México, México City, México \\ ${ }^{3}$ Laboratory of Bioprocesses, Department of Bioprocesses, Unidad Profesional Interdisciplinaria de Biotecnología \\ UPIBI-Instituto Politécnico Nacional, México City, México \\ Email: bautistadorian@yahoo.com.mx
}

Received December 13, 2011; revised January 27, 2012; accepted February 23, 2012

\begin{abstract}
A bacterial strain capable of Zinc and Lead biosorption was isolated from mine tailings. This strain showed the highest minimum inhibitory concentrations (MIC) of metals among other isolates in metal-resistance tests. Sorption tests were conducted placing $0.015 \mathrm{~g}$ of dry biomass in $10 \mathrm{ml}$ of metallic solution at fixed $\mathrm{pH}$. Contact was analyzed at different times (kinetics) and different initial concentrations (isotherm). The biomass was separated by centrifugation and the concentration of non-absorbed metal was determined using atomic absorption spectroscopy. The strain was identified by $16 \mathrm{~S}$ sequencing as Delftia tsuruhatensis. The order of toxicity of the metals to the bacterium was $\mathrm{Zn}>\mathrm{Pb}>\mathrm{Se}>\mathrm{Ni}$ $>\mathrm{Cu}=\mathrm{Al}$. Zinc and Lead absorption kinetics were adjusted to the pseudo second order equation $\left(\mathrm{r}^{2}=0.99\right)$, showing that equilibrium was reached at 40 and 20 min, respectively. Maximal absorption of $\mathrm{Pb}$ and $\mathrm{Zn}$ was 0.216 and 0.207 $\mathrm{mmol} \cdot \mathrm{g}^{-1}$, respectively; which can be considered a median magnitude capacity when compared to other biosorbents described in the literature.
\end{abstract}

Keywords: Biosorption; Langmuir and Freundlich Isotherms; Delftia Tsuruhatensis; $\mathrm{Pb}(\mathrm{II}) ; \mathrm{Zn}(\mathrm{II})$

\section{Introduction}

Heavy metals are among the more harmful pollutants that can be found in water. Potential damage to the public health in human population and other ecotoxicologial effects in living organism can be expected if contaminated water is consumed [1]. Several methods have been applied to remove these elements from water. However each of them is limited by specific technical and economic factors. Specifically when metals are found at low concentrations the removal from solutions using biomasses offers advantages over physico-chemical methods [2]. Thus the biosorption is a cost effective method for reach levels below of the permissible standards when contaminated water has metal content not far of this limits. The extent will depend on the capacity of the biological material.

Bacterial biomass has shown important potential for bioadsorption [3]. The search for bacterial strains with specialized capacities of adsorption is an important req- uisite for their potential use in practical methods [4].

The capacity and selectivity for biosorption of any given biological material cannot be determined a priori and can only be established experimentally. The great number of both possible bioadsorbent materials and materials to be adsorbed involves an enormous amount of experimental work to identify excellent bioadsorbents. Experiments on bioadsorption can be very demanding in terms of time and economic resources, rendering the delimitation of study objects (biosorbents-sorbates) very important [5].

The criteria most often used for selection of biosorbent materials have been economic as the low cost and the presence of the residue or biomass in abundant amount in nature [6]. The principal limitations with this approach are that the finding of good biosorbents (High capacity and selectivity) has a random nature and that the results are not reproducible when biomass residues of unknown and variable nature are applied. Although many biosorption studies have been reported until now there is not 
available knowledge that links a priori any biological criteria of the biosorbent with its biosorption performance. Therefore, it is important to test and compare the biosorption capacity of certain types of organisms. Thus it becomes valuable in order to trace potentials biosorbents with which carry out more specific studies.

Recent studies have shown that some microorganisms isolated from sites polluted with metals (i.e. resistant bacteria) are capable of absorbing metals [7-10]; but the advantages over other non-resistant strains have not been defined. There are special considerations for this group of biosorbing materials given by the interactions between the metals and either heavy metal-tolerant or resistant organisms [4]. In order to do a more extensive assessment of the capacity for biosorption of these microorganisms the principal aim of the present study was to evaluate the metallic sorption by a resistant bacterial strain isolated from a polluted site. The constants and biosorption capacity for metals (with which were showed the more resistance) were established. Finally a comparison with other biosorbents reported in literature was done.

\section{Materials and Methods}

\subsection{Isolation and Resistance Test}

We took samples from mine tailings in El Oro de Hidalgo and Zacualpan, State of México, México. Enrichments were done in nutritive broth additioned with $3 \mathrm{mM}$ of the six salts metal used $\left(\mathrm{ZnSO}_{4} \cdot 7 \mathrm{H}_{2} \mathrm{O}, \mathrm{NiCl}_{2} \cdot 6 \mathrm{H}_{2} \mathrm{O}, \mathrm{CuCl}_{2} \cdot 2 \mathrm{H}_{2} \mathrm{O}\right.$, $\mathrm{Na}_{2} \mathrm{SeO}_{3} \cdot 5 \mathrm{H}_{2} \mathrm{O}, \mathrm{Pb}\left(\mathrm{NO}_{3}\right)_{2}$ and $\left.\mathrm{Al}_{2}\left(\mathrm{SO}_{4}\right)_{3} \cdot 18 \mathrm{H}_{2} \mathrm{O}\right) .1 \mathrm{~g}$ of the mine tailings sample was inoculated in each of the six flask used and incubated at $35^{\circ} \mathrm{C}$ for $48 \mathrm{~h}$.

We isolated the microorganisms from the enriched media by dilution in a nutritive agar plate enriched with the aforementioned metals at a $0.5 \mathrm{mM}$ concentration. Cultures were incubated at $27^{\circ} \mathrm{C}$. The minimum inhibittory concentration (MIC) of the metal at which the bacteria showed growth was determined by reseeding by puncture in nutritive agar with different metal concentrations $(1,5,10,25$, and $50 \mathrm{mM})$. The strain with the highest MIC was selected.

\subsection{Biosorption Test}

Sorption tests were conducted with biomass grown in a nutritive broth centrifuged at $5000 \mathrm{rpm}$ for $15 \mathrm{~min}$ (ColeParmer Model 752400) and washed with sterile saline solution; the cellular pellet was dried at $80^{\circ} \mathrm{C}$ for $24 \mathrm{~h}$. Dry biomass $(0.015 \mathrm{~g})$ was placed in contact with $10 \mathrm{~mL}$ of a zinc and lead solution at different time intervals (kinetics) and different initial concentrations (isotherm). The $\mathrm{pH}$ at initial contact was measured. The biomass was subsequently separated by centrifugation $(3500 \mathrm{rpm}$ for
15 min, Cole-Parmer Model 752400) and the non-absorbed metal was determined in the supernatant by atomic absorption (AA). The procedure was done in triplicate. The indicator $q$, which represents the metallic capture per unit of weight of the biosorbent, was calculated by the simple difference method [5] according to the following equation:

$$
q=\frac{V i(C i-C f)}{S}
$$

where: $q=$ Sorption capacity $\left(\mathrm{mg} \cdot \mathrm{g}^{-1}\right) ; \mathrm{Vi}=$ Initial volume $(\mathbf{L}) ; C i=$ Initial concentration $\left(\mathrm{mg} \cdot \mathrm{L}^{-1}\right) ; C f=$ Final or equilibrium concentration $\left(\mathrm{mg} \cdot \mathrm{L}^{-1}\right) ; S=$ Biomass weight (g).

Using the mean and the standard error of the three series, the pseudo second-order equation was adjusted to the sorption kinetics [11]:

$$
q=\frac{t}{\left(1 / K_{s} q_{e q}^{2}+t / q_{e q}\right)}
$$

where: $t=$ Time $(\min ) ; K_{s}=$ Sorption constant; $q_{e q}=$ Sorption capacity in equilibrium $\left(\mathrm{mg} \cdot \mathrm{g}^{-1}\right)$. Linearization of $t / q$ vs. $t$ was used to estimate the value of the sorption constant $\left(K_{s}\right)$ and the sorption capacity in equilibrium $\left(q_{e q}\right)$.

Both commonly used models in literature, Langmuir y Freundlich, were used to represent the sorption phenomenon. The first is mathematically represented as:

$$
q=q_{\max } \frac{b C f}{1+b C f}
$$

where: $q_{\max }=$ Maximal sorption capacity $\left(\mathrm{mg} \cdot \mathrm{g}^{-1}\right) ; b=$ Affinity related coefficient. Linearization of $C f / q$ vs. $C f$ was used for estimating parameters.

Freundlich's isotherm is represented as:

$$
q=K_{f} C f^{(1 / n)}
$$

where: $K_{f}$ and $n$ are constants that indicate sorption capacity and sorption intensity, respectively. Linearization of $\operatorname{Ln} q$ vs. Ln $C f$ was used in this case.

\subsection{Molecular Strain Identification}

To determine the 16S rRNA gene sequence of the strain, cells were lysed according to Hiraishi et al. [12]. The $16 \mathrm{~S}$ rDNA fragment was amplified by PCR using the following universal primers: forward, 59-AGAGTTTGATCATGGCTCGA-39; and reverse, 59-GGCTACCTTGTTACGACTT-39 (positions 1510 - 1492). The sequence of the amplified 16S rDNA fragment (1400 bp) was analyzed using the Codon Code Aligner software (V.3.6.1) and compared with the National Center for Biotechnology Information (NCBI) database. 


\section{Results and Discussion}

\subsection{Characterization and Resistance of Isolated Strains}

A total of 12 bacterial strains were isolated and tested for their resistance against different metals ions. The bacterial strain with the highest minimum inhibitory concentrations (MIC) of metals was selected for biosorption studies. This was a gram-negative bacilli, which form irregular, cream-colored colonies, of viscous consistency and soft brilliant elevated surface. Compared to the NCBI GenBank sequences, the strain's sequence showed a 99\% homology to Delftia tsuruhantensis. This strain was isolated by Shigematsu et al. [13] from activated sludge in Tsuruhata, Kumamoto Prefecture, Japan, and identified as sp. nov. The strain belongs to the Pseudomonas III group, is a gram-negative bacillus and is considered a bacterium found in soil and water.

The strain exhibited the highest MIC with Zinc (25 $\mathrm{mM}$ ), being this metal in which it showed the best growth and represented the enrichment from which it was isolated. The MICs observed for other metals were $6 \mathrm{mM}, 3$ $\mathrm{mM},<1 \mathrm{mM},<1 \mathrm{mM},<0.5 \mathrm{mM}$ for Lead, Selenium, Cupper, Aluminum, and Nickel, respectively.

The MIC of Zinc for Delftia tsuruhatensis was slightly higher than the MIC for Bacillus circulans (22 mM) reported by Yilmaz [10]. Also the last two concentrations are higher than the MIC for an unidentified strain $(3 \mathrm{mM})$ reported by Ansari \& Malik [7]. These authors also report the MIC of lead as $5.57 \mathrm{mM}$, which is similar to the value shown by Delftia tsuruhatensis (6 $\mathrm{mM})$. These results were obtained in solid agar medium.

There are other reports of microbial resistance to metals, however the methodologies differ considerably from the one used in the present study. For example, some used an aqueous medium $[14,15]$ or even a solid medium, but adding the metallic solution once the medium had been solidified [16]. Therefore a direct comparison with our results is not appropriate. In general, the MICs showed by the isolates of the present study are higher than the reported in the literature using aqueous medium. It is generally considered that heavy metals are more toxic in liquid than in solid media due to a more dispersion in the culture [17].

Bacterial survival can vary according to different experimental conditions, as culture medium, metallic salt, stage at which the metallic solution is added, incubation periods, etc. Even metal toxicity may also vary according to the age of cultures used for testing resistance [16]. Also different survival indicators can be analyzed. In spite of the lack of a standardized methodology for testing microbial resistance to metals, the results of metal resistance in solid media of the present study can be considered in agreement with those reported in other works
$[7,10]$.

The presence of metals in the culture produced changes in color and consistency in every colony of the isolated strains, including Delftia tsuruhatensis. It has been suggested that this represents a bioaccumulation process of the metal to which the bacterial colony is exposed [18]. Another finding associated to the presence of metals in the culture medium was a diminished growth rate. This has been explained stating that the microorganism submitted to stress by metals deviate energy from growth to maintenance of other functions, as there is a greater demand of energy to resist metal toxicity [19].

\subsection{Sorption Kinetics}

The kinetic equation of pseudo second order $\left(r^{2}>0.99\right)$ was adjusted to the sorption of $\mathrm{Zn}$ and $\mathrm{Pb}$, indicating the usefulness of this equation to estimate the amount of metal adsorbed in a given time period. Other studies have proven the usefulness of this method in the biosorption phe- nomenon [20,21].

Sorption kinetics of $\mathrm{Zn}$ and $\mathrm{Pb}$ show that equilibrium was reached at 40 and $20 \mathrm{~min}$, respectively (Figure 1), indicating that $\mathrm{Pb}$ was absorbed more rapidly. Different results were reported by Puranik \& Paknikar [22] in the sorption kinetics for these metal ions using other bacterial biosorbent (Streptoverticillium cinnamoneum), where $\mathrm{Zn}$ was absorbed more rapidly than $\mathrm{Pb}$ reaching equilibrium at 15 and $30 \mathrm{~min}$, respectively. This difference suggests that a biosorbent can show special affinities in the sorption kinetics of certain metallic ions. However in other work Puranik et al. [23] showed that three bacterial species (Streptoverticillium cinnamoneum, Penicillium chrysogenum and Citrobacter sp.) were capable of absorbing lead and zinc, with equilibrium reached at $30 \mathrm{~min}$, independently from the strain, the metal, or the initial concentration used. Thus, it becomes evident the need to establish some basic guidelines to the sorption kinetics test in order to give support to the comparison of different results reported in the literature.

In general terms, sorption is a relatively rapid process, in which equilibrium is reached within minutes and, in most cases, within an hour at most. Salehi et al. [24] using Punica geranatum leaves reported the equilibrium at $30 \mathrm{~min}$ in the biosorption of $\mathrm{Pb}$. Hawari \& Mulligan [25] studied the sorption of lead into aerobic granules and observed that maximal sorption was reached at $30 \mathrm{~min}$. Fourest \& Roux [26] observed that $90 \%$ sorption of zinc occurred at $20 \mathrm{~min}$ at an optimal $\mathrm{pH}$ of 6 by $R$. arrhizus. Tunali et al. [27] observed maximal absorption of lead in 15 min with Bacillus sp. An extraordinary low rate in the kinetics of lead sorption was reported by Mustafiz et al. [28] using fish scales, reached equilibrium at 120 hours.

This range in the rates biosorption can be found with 
other metals and biosorbents. For instance, using Pantoea sp. equilibrium for $\mathrm{Cr}, \mathrm{Cd}$, and $\mathrm{Cu}$ sorption was reached at $15 \mathrm{~min}$ [29]. Using Chryseomonas luteola TEM 05 in sorption of $\mathrm{Al}$ and $\mathrm{Cr}$, equilibrium was reached at 60 and 90 minutes, respectively [30]. Tsezos et al. [31] used five non-identified bacterial strains for $\mathrm{Ag}$ and $\mathrm{Ni}$ sorption with equilibrium being reached at $60 \mathrm{~min}$.

A constant diminishing of metal concentration in the solution is not always present in sorption kinetics, in most cases, as equilibrium is reached; there are fluctuations in metal concentrations. Delftia tsuruhatensis showed this behavior (Figure 1). It is assumed that as soon as the adsorption process proceeds, the adsorbed sorbate tends to be released and eventually the rates of adsorption and desorption adjust in a state of equilibrium. Thus, a static equilibrium is reached in a relatively longer period than a dynamic equilibrium [28]. Once this equilibrium has been reached, adsorption becomes irreversible since very little metal will be released even if the solution remains under constant agitation [31].

\subsection{Adsorption Isotherms}

The determination of the equilibrium sorption isotherm is the most widely accepted way to test the sorption capacity of any biological material. This approach is based on the fact that the metal uptake mechanism is dependent on the initial metal ion concentration. Thus, increasing the initial metal ion concentration causes an increase in biosorption capacity of the biosorbent due to the probability of collution between metal ion and biosorbent increase in this condition which enhance the biosorption ability [5].

Regarding our results, the experimental data on $\mathrm{Pb}$ and Zn sorption fitted the Langmuir model better than the Freundlich model. The affinity coefficients in both models (b Langmuir and $\mathrm{n}$ Freundlich) were greater for $\mathrm{Pb}$ than for $\mathrm{Zn}$, generating a greater slope in the $\mathrm{Pb}$ isotherm. This means that the resistance to mass transfer in the

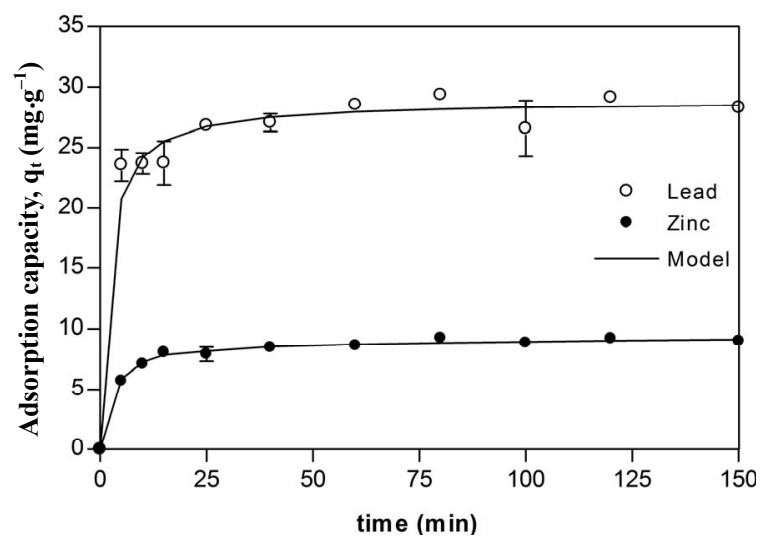

Figure 1. Zinc $(\bullet)$ and lead $(\circ)$ adsorption kinetics of Delftia tsuruhatensis; adjustment with the pseudo second order equation (羊). process of adsorption is overcome at lower initial concentrations for $\mathrm{Pb}$ than for $\mathrm{Zn}$ [32].

The maximal sorption capacity coefficients were also greater for $\mathrm{Pb}$ in both models $\left(\mathrm{q}_{\max }\right.$ Langmuir and $\mathrm{K}_{\mathrm{f}}$ Freundlich) (Figures 2 and 3, Table 1). However the differences in maximal adsorption capacities between $\mathrm{Pb}$ and $\mathrm{Zn}$ determined by the Langmuir model are in the same order as their differences in atomic weight. Therefore, when the adsorption capacity is expressed in $\mathrm{mmol} / \mathrm{g}$, the values for maximal adsorption capacity for the two metals show greater resemblance $\left(\mathrm{Pb} 0.216 \mathrm{mmol} \cdot \mathrm{g}^{-1}\right.$ and $\mathrm{Zn}$ $0.207 \mathrm{mmol} \cdot \mathrm{g}^{-1}$ ). Puranik [23] in a study with these two metals found that adsorptions of $\mathrm{Pb}$ and $\mathrm{Zn}$ by $\mathrm{S}$. cinnamoneum (57.7 and $21.3 \mathrm{mg} \cdot \mathrm{g}^{-1}$, respectively) were similar in their molar expression of capture $\left(0.28 \mathrm{mM} \cdot \mathrm{g}^{-1}\right.$ for $\mathrm{Pb}$ and $0.33 \mathrm{mM} \cdot \mathrm{g}^{-1}$ for $\mathrm{Zn}$ ). This suggest that the number of available binding sites in the biomass is similar to the adsorbed moles and this in turn similar to both metals.

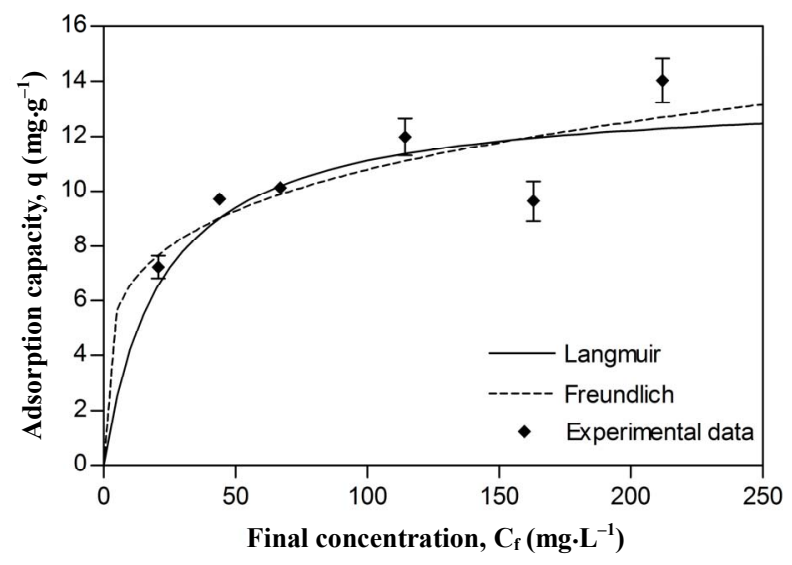

Figure 2. Metallic adsorption capacity (q) of Delftia tsuruhatensis at different final concentrations of Zinc. Adjustment with the Langmuir (羊) and Freundlich (---) adsorption isotherms.

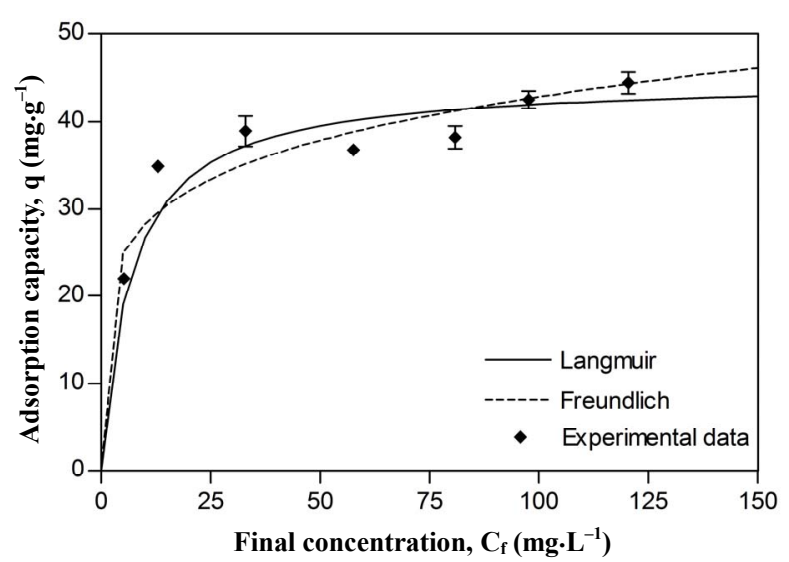

Figure 3. Metallic adsorption capacity (q) of Delftia tsuruhatensis at different final concentrations of Lead. Adjustment with the Langmuir (羊) and Freundlich (---) adsorption isotherms. 
Table 1. Parameters and adjustment of adsorption isotherms, Langmuir, Freundlich, and pseudo second order model, in zinc and lead adsorption by Delftia tsuruhatensis biomass.

\begin{tabular}{|c|c|c|c|c|c|c|c|c|c|}
\hline & \multicolumn{3}{|c|}{$\begin{array}{c}\text { Langmuir } \\
\text { isotherms model }\end{array}$} & \multicolumn{3}{|c|}{$\begin{array}{c}\text { Freundlich } \\
\text { isotherms model }\end{array}$} & \multicolumn{3}{|c|}{$\begin{array}{c}\text { Kinetics } \\
\text { model }\end{array}$} \\
\hline & $\mathrm{Q}_{\mathrm{m}}$ & $\mathrm{b}$ & $\mathrm{R}^{2}$ & $\mathrm{~K}_{\mathrm{F}}$ & $\mathrm{n}$ & $\mathrm{R}^{2}$ & $\mathrm{Q}_{\mathrm{m}}$ & $\mathrm{K}_{\mathrm{s}}^{2}$ & $\mathrm{R}^{2}$ \\
\hline & $\mathrm{mg} \cdot \mathrm{g}^{-1}$ & $\mathrm{~L} \cdot \mathrm{mg}^{-1}$ & & $\mathrm{mg} \cdot \mathrm{g}^{-1}$ & & & $\mathrm{mg} \cdot \mathrm{g}^{-1}$ & & \\
\hline $\mathrm{Pb}(\mathrm{II})$ & 44.8 & 0.147 & 0.988 & 18.66 & 5.54 & 0.803 & 28.8 & 0.018 & 0.99 \\
\hline $\mathrm{Zn}(\mathrm{II})$ & 13.56 & 0.045 & 0.904 & 3.97 & 4.61 & 0.711 & 9.37 & 0.036 & 0.99 \\
\hline
\end{tabular}

Two main variables have been suggested to explain the difference in adsorption for different metal ions by the same bioadsorbent. Thus a greater absorption of the metallic ion with lower charge/mass ratio [33] and smalller ionic radius [7] can be expected. However, these criteria do not explain the absorption of $\mathrm{Zn}$ and $\mathrm{Pb}$ by Delftia tsuruhatensis, since, in this case, greater adsorption of $\mathrm{Pb}$ than of $\mathrm{Zn}$ was achieved, i.e., greater adsorption of the element with larger ionic radius and lower charge/mass ratio (Table 2).

$\mathrm{A}$ greater $\mathrm{Pb}$ capture could be attributed to its ability to form more stable compounds, compared to $\mathrm{Zn}$, which is reflected in its covalent index [34-36].
Table 2. Atomic characteristics of $\mathrm{Zn}$ and $\mathrm{Pb}$.

\begin{tabular}{cccccc}
\hline & $\begin{array}{c}\text { Radius } \\
\text { Covalent } \\
\AA\end{array}$ & $\begin{array}{c}\text { Radius } \\
\text { Ionic } \\
\AA\end{array}$ & $\begin{array}{c}\text { Radius } \\
\text { Atomic } \\
\AA\end{array}$ & $\begin{array}{c}\text { Electronic } \\
\text { Configuration }\end{array}$ & $\begin{array}{c}\text { Atomic } \\
\text { weight }\end{array}$ \\
\hline Lead & 1.47 & 1.20 & 1.75 & $\begin{array}{c}{[\mathrm{Xe}]} \\
4 \mathrm{f}^{14} 5 \mathrm{~d}^{10} 6 \mathrm{~s}^{2} 6 \mathrm{p}^{2}\end{array}$ & 207.2 \\
Zinc & 1.31 & 0.74 & 1.38 & $\begin{array}{c}{[\mathrm{Ar}]} \\
3 \mathrm{~d}^{10} 4 \mathrm{~s}^{2}\end{array}$ & 65.39 \\
\hline
\end{tabular}

In comparison with other biosorbents reported in the literature the maximum adsorption capacity for $\mathrm{Zn}$ and $\mathrm{Pb}$ showed by Delftia tsuruhatensis is not among the highest. Table 3 shows the maximum capacity of lead biosorption of some biosorbents reported along with its principal operational conditions. Maximum adsorption capacity of Delftia tsuruhatensis $\left(44.4 \mathrm{mg} \cdot \mathrm{g}^{-1}\right.$ ) is only almost half of that reported for other metal-resistant bacteria Bacillus sp. $\left(92.3 \mathrm{mg} \cdot \mathrm{g}^{-1}\right)$. However these both indicators are far from the highest reported (769 - 255 $\mathrm{mg} \cdot \mathrm{g}^{-1}$ ). On the other hand according to the Table 4 where there is the maximum adsorption capacity of Zinc by different biosorbents, Delftia tsuruhatensis showed a modest performance $\left(14 \mathrm{mg} \cdot \mathrm{g}^{-1}\right)$. While other metal resistant bacteria reported a maximum capacity of 172.4 $\mathrm{mg} \cdot \mathrm{g}^{-1}[9]$. In this Table the highest capacity reported for Zinc is $641 \mathrm{mg} \cdot \mathrm{g}^{-1}$ [72].

Table 3. Lead adsorption capacity with different types of biological materials.

\begin{tabular}{|c|c|c|c|c|c|}
\hline \multirow{3}{*}{ Biosorbent Material } & \multicolumn{4}{|c|}{ LEAD } & \multirow{3}{*}{ Reference } \\
\hline & \multirow{2}{*}{$\frac{\mathrm{Q} \max }{\left(\mathrm{mg} \cdot \mathrm{g}^{-1}\right)}$} & & \multicolumn{2}{|c|}{ Operation } & \\
\hline & & $\mathrm{pH}$ & $\mathrm{T}$ & Biomass & \\
\hline & & & $\left({ }^{\circ} \mathrm{C}\right)$ & $\left(g \cdot L^{-1}\right)$ & \\
\hline Mucor rouxii $2-3$ & 769 & & & & {$[38]$} \\
\hline Corynebacterium glutamicum & 567.7 & 5 & 20 & 5 & [39] \\
\hline Bacillus firmus (1) Polysaccharide & 467 & & & & {$[40]$} \\
\hline Fucus vesiculosus ${ }^{4}$ & 336 & 6 & 25 & & [41] \\
\hline Sargassum natans ${ }^{4}$ & 310 & 3.5 & 26 & & [42] \\
\hline Chlorella fusca ${ }^{4}$ & 293 & 0.5 & & & [43] \\
\hline Ascophyllum nodosum ${ }^{4}$ & 280 & 6 & 25 & & [41] \\
\hline Gránulos anaerobicos & 255 & 3 & & & {$[25]$} \\
\hline Rhizopus nigricans $^{2}$ & 166 & & & & {$[26]$} \\
\hline Aerobic granules & 164.5 & & & & {$[32]$} \\
\hline Streptomyces rimosus & 135 & & & & {$[44]$} \\
\hline Arthrobacter sp. ${ }^{1}$ & 130 & 5 & 30 & 1.4 & {$[45]$} \\
\hline Rhizopus oligosporum ${ }^{2,3}$ & 126 & & & 5 & [46] \\
\hline Pennicillium chrysogenum ${ }^{2}$ & 116 & 4.5 & 23 & & [47] \\
\hline Rhizopus arrhizus & 104 & & & & {$[48]$} \\
\hline Streptomyces longwoodensis ${ }^{1}$ & 100 & 3 & 28 & 0.3 & [49] \\
\hline Streptomyces noursei & 99 & & & & [49] \\
\hline Azolla filiculoides ${ }^{5}$ Fern & 93 & & & & {$[50]$} \\
\hline Bacillus sp. ${ }^{{ }^{* *}}$ & 92.3 & & & & [27] \\
\hline Zoogloea ramigera & 81.23 & & & & {$[51]$} \\
\hline Pseudomonas aeruginosa PU 21 & 79.5 & & & & {$[52]$} \\
\hline Rhizopus arrhizus ${ }^{2}$ & 75 & 3.5 & 26 & & [42] \\
\hline Brevibacterium sp. & 74.6 & 6.3 & & & {$[53]$} \\
\hline Rhodotorula glutinis ${ }^{2,3}$ & 73.5 & & & & {$[54]$} \\
\hline Streptoverticillium cinnamoneum 2,3 & 57.7 & $5-7$ & & & {$[22]$} \\
\hline Aureobasidium pullulans ${ }^{2,3}$ & 56.9 & & & & {$[55]$} \\
\hline Pseudomonas putida & 56.2 & 6.5 & & & {$[56]$} \\
\hline
\end{tabular}




\section{Continued}

\begin{tabular}{|c|c|c|c|c|c|}
\hline Rhizopus arrhizus $^{2}$ & 55.6 & \multicolumn{2}{|c|}{$5-7$} & 3 & [26] \\
\hline Enterobacter sp. J1 & 50.9 & 5 & 25 & & {$[57]$} \\
\hline Rhizopus nigricans ${ }^{2,3}$ & 47 & & & & {$[58]$} \\
\hline Sago processing waste ${ }^{5}$ & 46.6 & & & & [59] \\
\hline Myriophyllum spicatum ${ }^{5}$ & 46.6 & & & & {$[60]$} \\
\hline Ceratophyllum demersum ${ }^{5}$ & 45 & & & & {$[60]$} \\
\hline Delftia tsuruhatensis ${ }^{1 * *}$ & 44.4 & 5 & 25 & 1.5 & Present study \\
\hline Alfalfa ${ }^{5}$ & 43 & & & & [61] \\
\hline Streptomyces noursei $^{1}$ & 36.5 & 6.1 & 30 & 3.5 & [62] \\
\hline E. coli K-12 6 & & & & & {$[63]$} \\
\hline Undaria pinnatfida ${ }^{4}$ & 30 & & & & [64] \\
\hline Punica geranatum (leaves) ${ }^{5}$ & 18.4 & 4 & & 10 & [24] \\
\hline Mucor rouxii $i^{2,3}$ & 17 & & & & {$[65]$} \\
\hline Phanerochaete chrysosporium & 12.34 & 4.5 & 27 & 2 & {$[66]$} \\
\hline E. coli K-12 ${ }^{6}$ Peptidoglycan & 10.3 & & & & {$[67]$} \\
\hline 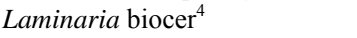 & 5.77 & & & & [68] \\
\hline Pennicillium digitatum ${ }^{2}$ & 5.5 & 5.5 & 25 & 6.5 & [69] \\
\hline Saccharomyces cerevisae ${ }^{3}$ & 2.7 & 5 & 25 & 2 & [70] \\
\hline Phanerochaete chrysosporium $^{2}$ & 2 & & & 6 & [71] \\
\hline
\end{tabular}

1: Bacterium; 2: Fungus; 3: Yeast; 4: Alga; 5: Plant. ${ }^{* *}$ Metal-resistant bacteria.

Table 4. Zinc adsorption capacity with different types of biological materials.

\begin{tabular}{|c|c|c|c|c|c|}
\hline \multirow{3}{*}{ Biosorbent Material } & \multirow{2}{*}{\multicolumn{2}{|c|}{$\mathrm{Q} \max$}} & \multicolumn{3}{|c|}{ ZINC } \\
\hline & & & Oper: & & Reference \\
\hline & $\left(\mathrm{mg} \cdot \mathrm{g}^{-1}\right)$ & $\mathrm{pH}$ & $\mathrm{T}$ & Biomass & \\
\hline & & & $\left({ }^{\circ} \mathrm{C}\right)$ & $\left(g \cdot L^{-1}\right)$ & \\
\hline$\overline{\text { Oscillatoria anguistissima }^{4}}$ & 641 & & & & [72] \\
\hline Bacillus firmus ${ }^{1}$ Polysaccaride & 418 & & & & {$[40]$} \\
\hline Thiobacillus ferroxidans $^{1{ }^{* *}}$ & 172.4 & 6 & 40 & & [9] \\
\hline Activated sludge & 138 & & & & [73] \\
\hline Aphanoteche halophytica ${ }^{4}$ & 133 & 6.5 & 30 & 0.2 & {$[74]$} \\
\hline Sargassum sp. ${ }^{4}$ & 118 & & & & {$[75]$} \\
\hline Streptomyces rimosus ${ }^{1}$ & 30 & 5.0 & 30 & 1 & [76] \\
\hline E. coli $\mathrm{K}-12$ & & & & & [63] \\
\hline (Peptidoglycan, LPS, proteins) $^{6}$ & 25.5 & & & & \\
\hline Activated sludge & 25 & 7 & & & [77] \\
\hline Streptoverticillium cinnamoneum ${ }^{2,3}$ & 21.3 & 5.5 & 28 & 2 & {$[22]$} \\
\hline Rhizopus arrhizus & 20 & & & & {$[48]$} \\
\hline Pseudomonas putida $\mathrm{CZ1}$ & 17.7 & 7.5 & 20 & 3 & {$[78]$} \\
\hline Saccharomyces cerevisae ${ }^{3}$ & 17 & & & & [79] \\
\hline Myriophyllum spicatum ${ }^{5}$ & 15.59 & & & & {$[60]$} \\
\hline Rhizopus nigricans $^{2}$ & 14 & $6-7$ & & 3 & {$[42]$} \\
\hline Ceratophyllum demersum 5 & 14 & 7.5 & & & {$[60]$} \\
\hline Delftia tsuruhatensis ${ }^{1 * *}$ & 14 & 6 & 25 & 1.5 & Present study \\
\hline Pseudomonas aeruginosa & 13.7 & & & & [80] \\
\hline Rhizopus arrhizus ${ }^{2}$ & 13.5 & 5.8 & 30 & 3.5 & {$[26]$} \\
\hline P. серасіа & 13.1 & 7.5 & & & {$[80]$} \\
\hline Aspergillus niger & 13 & & & & [79] \\
\hline Thiobacillus ferroxidans ${ }^{1}$ & 9.7 & 6.8 & 20 & 0.38 & [81] \\
\hline B. liqueniformis & & & & & {$[82]$} \\
\hline$(\gamma \text {-Glutamyl capsular polymer })^{6}$ & 9.7 & & & & \\
\hline Oxidized jute fibers & 8 & & & & {$[83]$} \\
\hline Pseudomonas syringae ${ }^{1}$ & 8 & & & 22 & {$[84]$} \\
\hline Pseudomonas putida ${ }^{1}$ & 6.9 & 4.5 & & & {$[56]$} \\
\hline Pennicillium chrysogenum ${ }^{2}$ & 6.5 & & & & [47] \\
\hline Jute fibers & 5.9 & & & & [83] \\
\hline Mucor rouxii $i^{2,3}$ & 4.9 & & & & [65] \\
\hline Streptomyces noursei ${ }^{1}$ & 1.6 & 0.28 & & & {$[62]$} \\
\hline Pennicillium spinulosum ${ }^{2,3}$ & 0.2 & $3.5-4.5$ & & & {$[85]$} \\
\hline
\end{tabular}

1: Bacterium; 2: Fungus; 3: Yeast; 4: Alga; 5: Plant; 6: Biopolymer. ${ }^{* *}$ Metal-resistant bacteria. 
Since the experimental protocols in the biosorption studies can vary the reported results are not always comparable in detail. However these can be important points of reference when the principal operational conditions as $\mathrm{pH}$, temperature and weight of biomass used are indicated.

The biosorption capacity of Delftia tsuruhatensis is important when it is compared with other kinds of materiales. As for example, Matheikal \& Yu [37] reported the sorption capacities for $\mathrm{Pb}$ of non-biological materials: Australian natural zeolite, $0.08 \mathrm{mmol} \cdot \mathrm{g}^{-1}$; pulverized activated carbon, $0.10 \mathrm{mmol} \cdot \mathrm{g}^{-1}$; granular activated carbon $\mathrm{F}-400,0.15 \mathrm{mmol} \cdot \mathrm{g}^{-1}$; and ionic exchange polymer (Duolite GT-73) $1.37 \mathrm{mmol} \cdot \mathrm{g}^{-1}$. The capacity for lead biosorption $\left(0.216 \mathrm{mmol} \cdot \mathrm{g}^{-1}\right)$ shown by Delftia tsuruhatensis is superior to that of the aforementioned materials with the exception of Duolite GT-73.

The last data show the reasons for which the biosorption is considered as a promising technology. When a good biosorbent is found a more specific studies are useful in order to both to understand the uptake mechanisms and to model more complex conditions i.e. multi metallic systems.

\section{Conclusion}

The $\mathrm{Zn}$ and $\mathrm{Pb}$ sorption capacities shown by Delftia tsuruhatensis can be considered of median magnitude compared to other reported biosorbents. Although Delftia tsuruhatensis shows notable resistance to $\mathrm{Zn}$ and $\mathrm{Pb}$, the sorption capacity for these metals did not prove superior than that of other reported biological materials. Based on our results, we suggest that microorganisms that are resistant to metals do not necessarily show a more efficient sorption capacity compared to other non resistant organisms, at least when using dry biomass in contact sorption tests. It is important to search for other options that could potentially improve the advantages of this technology.

\section{Acknowledgements}

We thank the National Council of Science and Technology (CONACYT) Mexico, for financial support given to the project "Formación Bacteriana de Nanopartículas Metálicas (CONACYT-53038)" and we thanks the Institute of Science and Technology of Distrito Federal ICYT DF for financial support given to the project "Bioacumulación de metales y formación de nanopartículas por microorganismos".

\section{REFERENCES}

[1] H. B. Bradl, C. Kim, U. Kramar and D. Stüben, "Interactions of Heavy Metals," In: H. B. Bradl, Ed., Heavy Metals in the Environment: Origin, Interaction and Remediation, Interface Science and Technology, Elsevier
Ltd., 2005, Vol. 6, pp. 28-164.

[2] R. H. Vieira and B. Volesky, "Biosorption: A Solution to pollution?" International Mycrobiology, Vol. 3, No. 1, 2000, pp. 17-24.

[3] K. Vijayaraghavan and Y. S. Yun, "Bacterial Biosorbents and Biosorption," Biotechology Advances, Vol. 26, No. 3, 2008, pp. 266-291. doi:10.1016/j.biotechadv.2008.02.002

[4] K. Chojnacka, "Biosorption and Bioaccumulation-The Prospects for Practical Applications," Environment International, Vol. 36, No. 3, 2010, 299-307. doi:10.1016/j.envint.2009.12.001

[5] B. Volesky, "Sorption and Biosorption," BV Sorbex Inc., Montreal-St. Lambert, 2003.

[6] S. S. Ahluwalia and D. Goyal, "Microbial and Plant Derived Biomass for Removal of Heavy Metals from Wastewater," Bioresource Technology, Vol. 98, No. 12, 2007, pp. 2243-2257.

[7] M. I. Ansari and A. Malik, "Biosorption of Nickel and Cadmium by Metal Resistant Bacterial Isolates from Agricultural Soil Irrigated with Industrial Wastewater," Bioresource Technology, Vol. 98, No. 16, 2007, pp. 31493153. doi:10.1016/j.biortech.2006.10.008

[8] A. I. Zouboulis, M. X. Loukidou and K. A. Matis, "Biosorption of Toxic Metals from Aqueous Solutions by Bacteria Strains Isolated from Metal-Polluted Soils," Process Biochemistry, Vol. 39, No. 8, 2004, pp. 909-916. doi:10.1016/S0032-9592(03)00200-0

[9] H.-L. Liu, B.-Y. Chen, Y.-W. Lan and Y.-C. Cheng, "Biosorption of $\mathrm{Zn}$ (II) and $\mathrm{Cu}$ (II) by the indigenous Thiobacillus thiooxidans," Chemical Engineering Journal, Vol. 97, No. 2-3, 2004, pp. 195-201. doi:10.1016/S1385-8947(03)00210-9

[10] I. E. Yilmaz, "Metal Tolerance and Biosorption Capacity of Bacillus circulans Strain EB1," Research in Microbiology, Vol. 154, No. 6, 2003, pp. 409-415. doi:10.1016/S0923-2508(03)00116-5

[11] Y. S. Ho and G. McKay, "Pseudo-Second Order Model for Sorption Processes," Process Biochemistry, Vol. 34, No. 5, 1999, pp. 451-465. doi:10.1016/S0032-9592(98)00112-5

[12] A. Hiraishi, Y. K. Shin, Y. Ueda and J. Sugiyama, “Automated Sequencing of PCR Amplified 16S rDNA on Hydrolink Gels," Journal of Microbiology Methods, Vol. 19, No. 2, 1994, pp. 145-154. doi:10.1016/0167-7012(94)90046-9

[13] T. Shigematsu, K. Yumihara, Y. Ueda, M. Numaguchi, S. Morimur and K. Kida, "Delftia tsuruhatensis sp. nov., a Terephthalate-Assimilating Bacterium Isolated from Activated Sludge," International Journal of Systematic and Evolutionary Microbiology, Vol. 53, 2003, pp. 1479-1483. doi:10.1099/ijs.0.02285-0

[14] A. Hassen, N. Saidi, Cherif and A. Boudabous, "Effects of Heavy Metals on Pseudomonas aeruginosa and Bacillus thuringiensis," Bioresource Technology, Vol. 65, No. 1-2, 1998, pp. 73-82. doi:10.1016/S0960-8524(98)00011-X

[15] W. Barabasz, B. Hetmanska and P. Tomasik, "The MetalMetal Interactions in Biological Systems. Part I. Esche- 
richia coli," Water, Air and Soil Pollution, Vol. 52, No. 3-4, 1990, pp. 337-375. doi:10.1007/BF00229442

[16] J. P. Chandy, "Heavy Metal Tolerance in Chromogenic and Non-Chromogenic Marine Bacteria from Arabian Gulf," Environmental Monitoring and Assessment, Vol. 59, No. 3, 1999, pp. 321-330. doi:10.1023/A:1006173722510

[17] G. Haferburg, M. Reinicke, D. Merten, G. Buchel and E. Kothe, "Microbes Adapted to Acidic Mine Drainage as Source for Strain Active in Retention of Aluminum or Uranium," Journal of Geochemical Exploration, Vol. 92, No. 2-3, 2007, pp. 196-204. doi:10.1016/j.gexplo.2006.08.011

[18] A. Hernández, P. R. Mellado and L. J. Martínez, "Metal Accumulation and Vanadium-Induced Multidrug Resistance by Environmental Isolates of Escherichia harmannii and Enterobacter cloacae," Applied and Environmental Microbiology, Vol. 64, No. 11, 1998, pp. 43174320.

[19] M. R. Timberley and L. P. Ian, "Microorganisms and Metal Pollutants," In: R. M. Maier, L. P. Ian and P. G. Charles, Eds., Environmental Microbiology, Academic Press, Cambridge, 2000, pp. 403-423.

[20] A. S. Luna, A. C. Da Costa, C. A. Henriques and M. H. Herbst, "Electron Paramagnetic Resonance and Atomic Absorption Spectrometry as Tools For the Investigation of $\mathrm{Cu}$ (II) Biosorption by Sargassum filipendula," Hydrometallurgy, Vol. 86, No. 1-2, 2007, pp. 105-113. doi:10.1016/j.hydromet.2006.11.008

[21] S. Karthikeyan, R. Balasubramanian and C. S. P. Iyer, "Evaluation of the marine Algae Ulva fasciata and Sargassum sp. for the Biosorption of $\mathrm{Cu}$ (II) from Aqueous Solution," Bioresource Technology, Vol. 98, No. 2, 2007, pp. 452-455. doi:10.1016/j.biortech.2006.01.010

[22] P. Puranik and K. M. Paknikar, "Biosorption of Lead and Zinc from solutions Using Streptoverticillum cinnamoneum Waste Biomass," Journal of Biotechnology, Vol. 55, No. 2, 1997, pp. 113-124. doi:10.1016/S0168-1656(97)00067-9

[23] P. R. Puranik, J. M. Modak and K. M. Paknikar, "A Comparative Study of Mass Transfer Kinetics of Metal Biosorption by Microbial Biomass," Hydrometallurgy, Vol. 52, 1999, pp. 189-197.

[24] P. Salehi, B. Asghari and F. Mohammadi, "Biosorption of $\mathrm{Ni}(\mathrm{II}), \mathrm{Cu}(\mathrm{II})$ and $\mathrm{Pb}(\mathrm{II})$ by Punica geranatum from Aqueous Solutions," Journal of Water Resource and Protection, Vol. 2, No. 8, 2010, pp. 701-705. doi:10.4236/jwarp.2010.28080

[25] A. H. Hawari and C. N. Mulligan, "Biosorption of Lead(II), Cadmium(II), Copper(II) and Nickel(II) by Anaerobic Granular Biomass," Bioresource Technology, Vol. 97, No. 4, 2006, pp. 692-700. doi:10.1016/j.biortech.2005.03.033

[26] E. Fourest and J. C. Roux, "Heavy Metal Biosorption by fungal Mycelial Byproducts: Mechanism and Influence of pH," Applied Microbiology and Biotechnology, Vol. 37, No. 3, 1992, pp. 399-403. doi:10.1007/BF00211001

[27] S. Tunali, A. Cabuk and T. Akar, "Removal of Lead and Copper Ions from Aqueous Solutions by Bacterial Strain Isolated from Soil," Chemical Engineering Journal, Vol.
115, No. 3, 2006, pp. 203-211. doi:10.1016/j.cej.2005.09.023

[28] S. Mustafiz, A. Basu and M. R. Islam, "A Novel Method for Heavy Metals Removal," Energy Resources, Vol. 24, No. 11, 2002, pp. 1043-1050. doi:10.1080/00908310290086905

[29] G. Ozdemir, N. Ceyhan, T. Ozturk, F. Akirmak and T. Cosar, "Biosorption of Chromium(VI), Cadmium(II) and Copper(II) by Pantoea sp. TEM 18," Chemical Engineering Journal, Vol. 102, No. 3, 2004, pp. 249-253. doi:10.1016/j.cej.2004.01.032

[30] G. Ozdemir and S. H. Baysal, "Chromium and Aluminum Biosorption on Chryseomonas luteola TEM 05," Applied Microbiology and Biotechnology, Vol. 64, No. 4, 2004, pp. 599-603. doi:10.1007/s00253-003-1479-0

[31] M. Tsezos, E. Remoudaki and Angelatau, "A Systematic Study on Equilibrium and Kinetics of Biosorptive Accumulation: The Case of $\mathrm{Ag}$ and $\mathrm{Ni}$," International Biodeterioration and Biodegradation, Vol. 35, No. 1-3, 1995, 129-153. doi:10.1016/0964-8305(95)00049-B

[32] Y. Liu, H. Xu, S. F. Yang and J. H. Tay, "A general Model for Biosorption of $\mathrm{Cd}^{2+}, \mathrm{Cu}^{2+}$, and $\mathrm{Zn}^{2+}$ by Aerobic Granules," Journal of Biotechnology, Vol. 102, No. 3, 2003, pp. 233-239. doi:10.1016/S0168-1656(03)00030-0

[33] A. Esposito, F. Pagnanelli, A. Lodi, C. Solisio and F. Veglió, "Biosorption of Heavy Metals by Sphaerotilus natans: An Equilibrium Study at Different pH and Biomass Concentrations," Hydrometallurgy, Vol. 60, No. 2, 2001, pp. 129-141.

[34] C. Can and W. Jianlong, "Influence of Metal Ionic Characteristic on Their Biosorption Capacity by Saccharomyces cerevisiae," Applied Microbiology and Biotechnology, Vol. 74, No. 4, 2007, 911-917. doi:10.1007/s00253-006-0739-1

[35] K. Chandrasekhar, C. T. Kamala, N. S. Chary and Y. Anjanuyuku, "Removal of Heavy Metal Using Plant Biomass with Reference to Environmental Control," International Journal of Mineral Process, Vol. 68, No. 1-2, 2003, pp. 37-45. doi:10.1016/S0301-7516(02)00047-9

[36] J. M. Brady and J. M. Tobin, "Binding of Hard and Soft Metals Ions to Rhizopus arrhizus Biomass," Enzyme and Microbial Technology, Vol. 17, No. 9, 1995, pp. 791-796. doi:10.1016/0141-0229(95)00142-R

[37] J. T. Matheikal and Q. Yu, "Biosorption of Lead(II) and Copper(II) from Aqueous Solutions by Pre-Treated Biomass of Australian Marine Algae," Bioresource Technology, Vol. 69, No. 3, 1999, pp. 223-229. doi:10.1016/S0960-8524(98)00196-5

[38] W. Lo, H. Chua, K. H. Lam and S. P. Bi, "A Comparative Investigation on the Biosorption of Lead by Filamentous Fungal Biomass," Chemosphere, Vol. 39, No. 15, 1999, pp. 2723-2736. doi:10.1016/S0045-6535(99)00206-4

[39] S. B. Choi and Y.-S. Yun, "Lead Biosorption by Waste Biomass of Corynebacterium glutamicum Generated from Lysine Fermentation Process," Biotechnology Letters, Vol. 26, No. 4, 2004, pp. 331-336. doi:10.1023/B:BILE.0000015453.20708.fc

[40] H. Salehizadeh and S. A. Shojaosadati, "Removal of Me- 
tal Ions from Aqueous Solutions by Polysaccharide Produced from Bacillus firmus," Water Research, Vol. 37, No. 17, 2003, 4231-4235. doi:10.1016/S0043-1354(03)00418-4

[41] Z. R. Holan and B. Volesky, "Biosorption of Lead and Nickel by Biomass of Marine Algae," Biotechnology and Bioengineering, Vol. 43, No. 11, 1994, pp. 819-825. doi:10.1002/bit.260431102

[42] B. Volesky, "Removal of Heavy Metals by Biosorption," In: M. R. Ladisch and A. Bose, Eds., Harnessing Biotechnology for the $21^{\text {st }}$ Century, American Chemical Society, Washington DC, 1992, pp. 462-466.

[43] B. Wehreim and M. Wettern, "Biosorption of Cadmium, Copper and Lead by Isolated Mother Cell Wall and Whole Cells of Chlorella fusca," Applied Microbiology and Biotechnology, Vol. 41, No. 6, 1994, pp. 331-343. doi:10.1007/BF00167291

[44] A. Selatnia, A. Boukazoula, N. Kechid, M. Z. Bakhti, A. Chergi and Y. Kerchich, "Biosorption of Lead(II) from Aqueous Solution by a Bacterial Dead Streptomyces rimosus biomass," Biochemical Engineering Journal, Vol. 19, No. 2, 2004, pp. 127-135. doi:10.1016/j.bej.2003.12.007

[45] F. Veglio, F. Beolchini and A. Gasbarro, "Biosorption of Toxic Metals: An Equilibrium Study Using Free Cells of Arthrobacter sp.," Process Biochemistry, Vol. 32, No. 2, 1997, pp. 99-105. doi:10.1016/S0032-9592(96)00047-7

[46] A. B. Ariff, M. Mel, M. A. Hasan and M. I. A. Karim, "The Kinetics and Mechanism of Lead(II) Biosorption by Powderized Rhizopus oligosporum," World Journal of Microbiology and Biotechnology, Vol. 15, No. 2, 1999, pp. 291-298. doi:10.1023/A:1008995026987

[47] H. Niu, X. S. Xiu, J. H. Wang and B. Volesky, "Removal of Lead from Aqueous Solution by Penicillum Biomass," Biotechnology and Bioengineering, Vol. 42, No. 6, 1993, pp. 785-787. doi:10.1002/bit.260420615

[48] A. Kapoor and T. Viraraghavan, "Fungal BiosorptionAn Alternative Treatment Option for Heavy Metal Bearing Wastewater: A Review," Bioresource Technology, Vol. 53, No. 3, 1995, pp. 195-206. doi:10.1016/0960-8524(95)00072-M

[49] N. Friis and P. Myers-Keith, "Biosorption of Uranium and Lead by Streptomyces longwoodensis," Biotechnology and Bioengineering, Vol. 28, No. 1, 1986, pp. 21-28. doi:10.1002/bit.260280105

[50] D. Sanyahumbi, J. R. Duncan, M. Zhao and R. Vanhile, "Removal of Lead from Solutions by the Non-Viable Biomass of the Water Fern Azolla filiculoides," Biotechnology Letters, Vol. 20, No. 8, 1998, pp. 745-747. doi:10.1023/A:1005386703592

[51] Y. Sag and T. Kutsal, "Fully Competitive Biosorption of Chromium (VI) Iron (III) Ions from Binary Metal Mixtures by $R$. arrhizus: Use of the Competitive Langmuir Model," Process Biochemistry, Vol. 31, No. 6, 1996, pp. 573-585. doi:10.1016/S0032-9592(96)00003-9

[52] J. S. Chang, R. Law and C. Chang, "Biosorption of Lead, Copper and Cadmium by Biomass of Pseudomonas aeruginosa PU21," Water Research, Vol. 31, No. 7 1997, pp. 1651-1658. doi:10.1016/S0043-1354(97)00008-0
[53] A. Vecchio, C. Finoli, D. Di Simine and V. Andreoni, "Heavy Metal Biosorption by Bacterial Cells Fresenius," Journal of Analytical Chemistry, Vol. 361, No. 4, 1998, pp. 338-342. doi:10.1007/s002160050899

[54] D. H. Cho and E. Y. Kim, "Characterization of $\mathrm{Pb}^{2+}$ Biosorption from Aqueous Solution by Rhodotorula glutinis," Bioprocess Biosystem Engineering, Vol. 25, No. 5, 2003, pp. 271-277. doi:10.1007/s00449-002-0315-8

[55] J. H. Suh, J. W. Yun and D. S. Kim, "Comparison of $\mathrm{Pb}^{2+}$ Accumulation Characteristics between Live and Dead Cells of Saccharomyces cerevisiae and Aurebasidium pullulans," Biotechnology Letters, Vol. 20, No. 3, 1998, pp. 247-251. doi:10.1023/A:1005373718222

[56] R. Pardo, M. Herguedas, E. Barrado and M. Veja, "Biosorptium of Cadmium, Copper, Lead and Zinc by Inactive Biomass of Pseudomonas putida," Analytical Bioanalytical Chemistry, Vol. 376, No. 1, 2003, pp. 26-32. doi:10.1007/s00216-003-1843-Z

[57] W. B. Lu, J. J. Shi, C. H. Wang and J. S. Chang, "Biosorption of Lead, Copper and Cadmium by an Indigenous Isolate Enterobacter sp. J1 Possessing High Heavy Metal Resistance," Journal of Hazardous Materials, Vol. 134, No. 1-3, 2006, pp. 80-86. doi:10.1016/j.jhazmat.2005.10.036

[58] L. Zhang, L. Zhao, Y. Yu and C. Chen, "Removal of Lead from Aqueous Solution by Nonliving Rhizopus nigricans," Water Research, Vol. 32, No. 5, 1998, pp. 1437 1444. doi:10.1016/S0043-1354(97)00348-5

[59] S. Y. Quek, D. A. J. Wase and C. F. Forster, "The Use of Sago Waste for the Sorption of Lead and Copper," Water S.A., Vol. 24, No. 3, 1998, pp. 251-256.

[60] O. Keskinkan, M. Z. L. Goksu, M. Basibuyuk and C. F. Forster, "Heavy Metal Adsorption Properties of a Submerged Aquatic Plant Ceratophyllum demersum," Bioresource Technology, Vol. 92, No. 2, 2004, pp. 197-200. doi:10.1016/j.biortech.2003.07.011

[61] K. J. Tiemann, J. L. Gardea-Torresdey, G. Gamez, K. Dokken and S. Sias, "Use of X-Ray Adsorption Spectroscopy and Esterification to Investigate Chromium(III) and Nickel(II) Ligand in Alfalfa Biomass," Environmental Science and Technology, Vol. 33, No. 1, 1999, pp. 150-154. doi:10.1021/es9804722

[62] B. Mattuschka and G. Straube, "Biosorption of Metals by a Waste Biomass," Journal of Chemical Technology and Biotechnology, Vol. 58, No. 1, 1993, pp. 57-63. doi: $10.1002 /$ jctb. 280580108

[63] T. J. Beveridge and S. F. Koval, "Binding of Metals to Cell Envelopes of Escherichia coli K-12," Applied Environmental Microbiology, Vol. 42, No. 2, 1981, pp. 876887.

[64] Y. H. Kim, Y. J. Yoo and H. Y. Lee, "Characteristic of Lead Adsorption by Undaria pinnatifida," Biotechnology Letters, Vol. 17, No. 3, 1995, pp. 354-350. doi:10.1007/BF01190651

[65] G. Yan and T. Viraraghavan, "Heavy-Metal Removal from Aqueous Solution by Fungus Mucor rouxii," Water Research, Vol. 37, No. 18, 2003, pp. 4486-4496. doi:10.1016/S0043-1354(03)00409-3 
[66] Q. Li, S. Wu, G. Liu, X. Liao, X. Deng, D. Sun, Y. Hu and Y. Huang, "Simultaneous Biosorption of Cadmium(II) and Lead(II) Ions by Pretreated Biomass of Phanerochaete chrysosporium," Separation and Purification Technology, Vol. 34, No. 1-3, 2004, pp. 135-142. doi:10.1016/S1383-5866(03)00187-4

[67] B. D. Hoyle and T. J. Beveridge, "Metal Binding by the Peptidoglycan Sacculus of Escherichia coli K-12," Canadian Journal of Microbiology, Vol. 30, No. 2, 1984, pp. 204-211. doi:10.1139/m84-031

[68] U. Soltmann, S. Matys, G. Kieszig, W. Pompe and H. Böttcher, "Algae-Silica Hybrid Materials for Biosorption of Heavy Metals," Journal of Water Resource and Protection, Vol. 2, No. 2, 2010, pp. 115-122. doi:10.4236/jwarp.2010.22013

[69] M. Galun, E. Galun, B. Z. Siegel, P. Keller, H. Lehr and S. M. Siegel, "Removal of Metal Ions from Aqueous Solution by Penicillum Biomass: Kinetics and Uptake Parameters," Water Air Soil Pollution, Vol. 33, No. 3-4, 1987, pp. 359-371. doi:10.1007/BF00294204

[70] C. P. Huang, C. P. Huang and A. L. Morehart, "The Removal of $\mathrm{Cu}$ (II) from Dilute Aqueous Solution by Saccharomyces cerevisiae," Water Research, Vol. 24, No. 4, 1990, pp. 433-439. doi:10.1016/0043-1354(90)90225-U

[71] R. Say, A. Denizli and M. Y. Arica, "Biosorption of Cadmium(II), Lead(II) and Copper(II) with the Filamentous fungus Phanerochaete chrysosporium," Bioresource Technology, Vol. 76, No. 1, 2001, pp. 67-70 doi:10.1016/S0960-8524(00)00071-7

[72] P. Ahuja, R. Gupta and R. K. Saxena, " $\mathrm{Zn}^{2+}$ Biosorption of Oscillatoria anguistissima," Process Biochemistry, Vol. 34, No. 1, 1999, pp. 77-85. doi:10.1016/S0032-9592(98)00072-7

[73] A. Artola and M. Rigola, "Selection of Optimum Biological Sludge for Zinc Removal from Wastewater by a Biosorption Process," Biotechnology Letters, Vol. 14, No. 2, 1992, pp. 1199-1204. doi:10.1007/BF01027028

[74] A. Incharoensakdi and P. Kitjaharn, "Zinc Biosorption from Aqueous Solution by a Halotolerant Cyanobacterium Aphanothece halophytica," Current Microbiology, Vol. 45, No. 4, 2002, pp. 261-264. doi:10.1007/s00284-002-3747-0

[75] E. Valdam and S. G. F. Leite, "Biosorption of Cd, Zn, and $\mathrm{Cu}$ by Sargassum sp. Waste Biomass," Bioprocess Engineering, Vol. 22, No. 2, 2000, pp. 171-173. doi:10.1007/PL00009109
[76] N. Mameri, N. Boudries, L. Addour, D. Belhocine, H. Lounici, H. Grib and A. Pauss, "Batch Zinc Biosorption by a Bacterial Non-Living Streptomyces rimosus Biomass," Water Research, Vol. 33, No. 6, 1999, pp. 1347-1354. doi:10.1016/S0043-1354(98)00349-2

[77] P. Solaris, K. A. Zouboulis, Matis and G. A. Stalidis, "Removal of Toxic Metals by biosorption onto Non-Living Sewage Sludge," Separation Science and Technology, Vol. 31, No. 8, 1996, pp. 1075-1092. doi: $10.1080 / 01496399608001335$

[78] X. C. Chen, Y. P. Wang, Q. Lin, J. Y. Shi, W. X. Wu and Y. X. Chen, "Biosorption of Copper(II) and Zinc(II) from Aqueous Solution by Pseudomonas putida CZ1," Colloids and Surfaces B: Biointerfaces, Vol. 46, No. 2, 2005, pp. 101-107. doi:10.1016/j.colsurfb.2005.10.003

[79] B. Volesky and H. A. May-Phillips, "Biosorption of Heavy Metals by Saccharomyces cerevisiae," Applied Microbiology and Biotechnology, Vol. 42, No. 5, 1995, pp. $797-$ 806. doi:10.1007/BF00171964

[80] I. Savvaidis, M. N. Hughes and R. K. Poole, "Differential Pulse Polarography: A Method of Directly Measuring Uptake of Metal Ions by Live Bacteria without Separation of Biomass and Medium," FEMS Microbiology Letters, Vol. 92, No. 2, 1992, pp. 181-186. doi:10.1111/j.1574-6968.1992.tb05256.x

[81] R. J. Celaya, J. A. Noriega, J. H. Yeomans, L. J. Ortega and A. Ruiz-Manri Quex, "Biosorption of Zinc(II) by Theobacillus ferroxidans," Bioprocess Engineering, Vol. 22, No. 6, 2000, pp. 539-542. doi: $10.1007 / \mathrm{s} 004499900106$

[82] R. J. McLean, D. Beauchemin, L. Clapham and T. J. Beveridge, "Metal-binding Characteristic of the GammaGlutamyl Capsular Polymer of Bacillus licheniformis ATCC 9945," Applied and Environmental Microbiology, Vol. 56, No. 12, 1990, pp. 3671-3677.

[83] S. R. Shukla and R. S. Pai, "Adsorption of Cu(II), Ni(II) and $\mathrm{Zn}(\mathrm{II})$ on Modified Jute Fibres," Bioresource Technology, Vol. 96, No. 13, 2005, pp. 1430-1438. doi:10.1016/j.biortech.2004.12.010

[84] J. P. S. Cabral, "Selective Binding of Metal Ions to Pseudomonas syringae Cells," Microbes, Vol. 71, No. 286, 1992, pp. 47-53.

[85] C. C. Townsley and I. S. Ross, "Copper Uptake by Penicillum spinulosum," Microbes, Vol. 44, No. 178, 1985, pp. $125-134$ 